\title{
THE IMPORTANCE OF THE ACCESSIBILITY TO CELL THERAPY IN BRAZIL
}

\author{
Fernando Barroso Duarte' ${ }^{1}$ Lúcia Silla², Nelson Hamerschlak ${ }^{3}$ \\ 1 Hospital Universitário Walter Cantídio( HUWC) - 2 Universidade Federal do Rio Grande do Sul (UFRGS) \\ 3 Hospital Israelita Albert Einstein (HIAS)
}

Running title: ACCESSIBILITY TO CT IN BRAZIL

Correspondence to: Fernando Barroso (nutriquimio@gmail.com)

Due to the undeniable importance of cell therapy (CT) in current medicine [1-4], especially in the area of onco-hematology, some initiatives were taken by SBTMO, the first of which was the incorporation of the name TC to the name of our society, considering that the Hematopoietic Stem Cell Transplantation (HSCT) itself is one of the most successful treatments with CT. Another important decision was the creation of a working group to discuss in greater depth these issues, having as the first concrete act the publication of the Brazilian Consensus on CT in the latest edition of the SBTMO magazine.

Continuing these actions, a regional meeting was held on 27 and 28 May, 2021, with the VIII Fani Job Hematology Meeting, coordinated by Professor Lúcia Silla, from Porto Alegre, with a topic exclusively dedicated to CT. Dr. Lúcia is internationally renowned for her dedication to research with Natural Killer (NK) cells [5] but she held an event in a comprehensive way, covering all current aspects, involving Gene Therapy (GT) and CAR-T-cells.

Several points were addressed, from pre-clinical studies, cell expansion platforms, licensing and manufacturing of cells for NK and CAR-T cell, infusion of donor lymphocytes and their interrelationship with the CAR-T cell, in addition to aspects of these therapies in Europe and in the United States.

Another very relevant issue was the discussion of clinical trials in advanced therapies presently going on in Brazil, including representatives of centers from the northeast, southeast, and south of the country, with the special participation of Dr Renata Parca from ANVISA and Dr Antonio Carlos Campos de Carvalho.

Another great lesson we had was listening to the experience of Barcelona in the development and licensing of CAR-T cell products by Dr Alvaro Urbano Ispizua, a model that draws attention for its ex- cellence and for the possibility of covering several hospitals in Spain, as well as being an example in cooperative work, which we believe is essential at this time to improve accessibility.

We ended the last day with a panel of 28 participants, in addition to the audience, who actively participated with questions and comments, with Dr. Carmem Bonfim as the transplant and pediatrics representative, who made excellent contributions.

The discussion on academic and industrial CT was a huge learning experience for all of us.

It was very important to know the initiatives of Brazilian groups, such as genetic studies and clinical studies with NK already developed at the Hospital de Clínicas de Porto Alegre, in addition to the efforts of the Faculty of Medicine of Ribeirão Preto, in partnership with Butantan Institute to develop a vector for CAR-T cells, preclinical studies at Fiocruz, clinical studies at Hospital Albert Einstein and Hospital São Rafael with CAR-Tcells. Which validates the need to carry out a national consortium for the growth of CT across the country.

The standards generated by CONEP and ANVISA, along with the definitions of remuneration for this work and cooperation were also addressed, so that they are officially made feasible, and among these initiatives, the beginning of official negotiations between SBTMO and international partners, such as the experience of Prof. Alvaro Urbano Ispizua in Barcelona and the collaboration of Dr Marcos de Lima from Ohio university.

With this aggregating and inclusive spirit, understanding the need to join forces so that we can have a robust CT program in Brazil as we presently do in $\mathrm{HSCT}$, the meeting was concluded by Dr Lucia Silla with the participation of the president of SBTMO, Dr. Nelson Hamerschlak and the future president Dr. Fernando Barroso. 


\section{THE PARTICIPANTS WERE:}

- Lucia Silla (RS): UFRGS

- Martin Bonamino: INCA and FIOCRUZ

- Virginia Picanço e Castro (SP): Blood Center of Ribeirão Preto

- Edina Poletto (RS): Universidade Federal do Rio Grande do Sul

- Karina Tozatto Maio (SP): HCFMUSP e HIAE

- Dean A. Lee, MD PhD: Nationwide Children's Hospital/The Ohio State University

- Belinda Simões: Senior consultant technical university Munich

- Lucila Kerbauy (SP): HIAE

- Roberto Giugliani (RS): Federal University of Rio Grande do Sul (UFRGS), Porto Alegre, RS, Brazil

- Sang Han (SP): Escola paulista de medicina, Universidade federal de São Paulo (EPM-UNIFESP)

- Úrsula Matte (RS): UFRGS and HCPA

- Hans Kolb: Universitaets-Klinik, Munich

- Andrea Velardi, MD (Itália): University Hospital, Italy

- Marcos de Lima: Ohio State University

- Nelson Hamerschlak: Hospital Israelita Albert Einstein

- Álvaro Urbano Ispizua (Espanha): Hospital Clínic de Barcelona

- Renata Parca: Anvisa

- Antônio Carlos Campos de Carvalho (RJ): Carlos Chagas Biohys

- Marco Salvino (BA): UFBA

- Vanderson Rocha: HCFMUSP

- Jose Mauro Kutner (SP): Hospital Israelita Albert Einstein

- Karina Tozatto Maio (SP)

- Gabriella Dalmolin (RS): Hospital de Clínicas de Porto Alegre (HCPA)

- Milena Soares (BA)

- Virginia Picanço e Castro (SP)

\section{REFERENCES}

1. June $\mathrm{CH}$, Sadelain M. Chimeric Antigen Receptor Therapy. N Engl J Med. 2018;379(1):64-73.

2. Chong EA, Ruella M, Schuster SJ, Lymphoma Program Investigators at the University of Pennsylvania. Five-Year Outcomes for Refractory B-Cell Lymphomas with CAR T-Cell Therapy. N Engl J Med. 2021;384(7):673-4.

3. Rosenbaum L. Tragedy, Perseverance, and Chance - The Story of CAR-T Therapy. N Engl J Med. 2017;377(14):1313-5.
4. Journal of Bone Marrow Transplantation and Cellular Therapy. Rio de Janeiro: SBTMO. Vol. 4, n. 4, 2021. Available from: https://www.jbmtct. com.br/seer/index.php/jbmtct/issue/view/5/ Journal\%20of\%20Bone\%20Marrow\%20Transplantation $\% 20$ and $\% 20$ Cellular\%20Therapy $\% 20$ volume $\% 204 \% 20$ n $\%$ C3\%BAmero $\% 201 \% 20$ 2021.

5. Silla L. Double-bright (CD56bright/CD16bright) natural killer cell adoptive immunotherapy for SARS-CoV-2. Br J Haematol. 2020;190(6):e322-3. 